\title{
If There's A Heaven
}

By Eric A. Dowson, Nanaimo, B.C.

(EDITOR'S NOTE: Some time ago we published a little poem, called the "River Song," by Mr. Dowson. Recently we were very pleased to receive from him one of his little books of poems called "Country Places and Other Poems."

Many of these poems reflect so well the atmosphere of the Prairie and those who, in the homesteading days toiled to clear the land, while their hearts were filled with the glory of Nature, that we could not refrain from publishing another, and hope that more will appear from time to time.

We met him almost twenty years ago at Tisdale. His cabin near there by the little stream which runs north to empty into the Saskatchewan, was the centre from which eminated his poetic thoughts of contentment inspired by the world of Nature about. These things which inspired him most are best expressed in his own words:

"I am often asked how and where the poems were written. Most of them came during those day" on the farm. Farming is a busy life but the farmer works and lives in and out of a door that is teeming with interest. And these poems are mostly about the "out of door." During a ten-hour day piowing, the attention is not entirely taken up with plow adjustments or attention to the horses. There is the smell of new turned soil, the sight of cloud formations, changing all the time, autumn tints, painting the landscape, the glint of a river trickling its way through the valley, birds singing, gulls following the plow, geese honking overhead. The job is anything but dull, and the plowman is either drinking in all this outdoor interest or mooning over little farm worries and the general problems of life. I did both, as all plowman do. It is an ideal setting for writing poetry."

If there's a heaven to beckon me After this life is done,

I'll want no stately mansions there, Where golden roadways run.

I think that, God may let me see, After the soul's new birth,

Some of the common things I knew In the land I loved on Earth.

A cozy cabin must be there, Built on a river bank.

A. rin: lined with poplar trees, And sedges growing rank.

Where mallards haunt the river pools And geese honk through the sky.

Where music fills the willow bluffs As a prairie wind sweeps by.

I'll hear the song of meadowlarks And the startled partridge whirr,

As I walk a woodland trail again When sap begins to stir.
I'll want to catch the smell of soil After a Springtime rain,

And watch a prairie sun go down Across a field of grain.

I'll want the stir of harvest there, And the golden tints of Fall

When Prairie fields reflect the bliss Of Indian Summer's call.

And from my cabin window too, Sometimes I'll like to see

A winter scene, all crystal clear, Before the ice goes free.

At times I think that cabin home Shall be a rendezvous

Where Prairie neighbors meet again, Just as we used to do.

And God, I'm sure, will grant to me One little thing beside.

To share the Heaven of my choice, A loved one by my side. 